PressAcademia Procedia

\title{
FINANCIAL INCLUSION: THE CASE OF TURKEY
}

\author{
DOI: 10.17261/Pressacademia.2021.1515 \\ PAP- V.14-2021(41)-p.150-151
}

\author{
Suat Teker ${ }^{1}$, Dilek Teker ${ }^{2}$, Halit Guzelsoy ${ }^{3}$ \\ ${ }^{1}$ Isik University, Department of Business, Sile Campus, Istanbul, Turkey. \\ suat.teker@isikun.edu.tr ,ORCID: 0000-0002-7981-3121 \\ ${ }^{2}$ ssik University, Department of Business, Sile Campus, Istanbul, Turkey. \\ dilek.teker@isikun.edu.tr, ORCID: 0000-0002-3893-4015 \\ ${ }^{3}$ Isik University, Department of Business, Sile Campus, Istanbul, Turkey. \\ halit.guzelsoy@isikun.edu.tr, ORCID: 0000-0002-4600-4563
}

\section{To cite this document}

Teker, S., Teker, D., Guzelsoy, H., (2021). Financial inclusion: the case of Turkey. PressAcademia Procedia (PAP), 14, 150-151.

Permanent link to this document: http://doi.org/10.17261/Pressacademia.2021.1515

Copyright: Published by PressAcademia and limited licensed re-use rights only.

\section{ABSTRACT}

Purpose- Financial inclusion is defined as a process that ensures the ease of access, availability and usage of the formal financial system for all members of an economy by emphasizing the use of accessibility, availability of financial services. A financial sector is measured and compared on four main features; debt is the size of financial institutions, access is the access and use of financial services by the users, efficiency is the efficiency in the provision of financial services, stability is the stability in the provision of financial services. Financial inclusion, in short, is adults' access and use of financial services. The purpose of this paper is to measure the level of financial inclusion of Turkey for the period of 2000-2017.

Methodology- The World Bank data covering 2000-2017 period is extracted for Turkey. The whole financial system of Turkey is defined to be a combination of banks, nonbanks financial institutions and exchange markets. The related indicators for each of the subsections of the Turkish financial system are determined for banks, nonbanks and exchange markets providing a continued data stream. Thus, 32 indicators for banks, 6 indicators for nonbanks and 16 indicators for exchange markets are determined for the financial inclusion index for Turkey. All indicators are in percentages. All individual indicators are summed for the computation of subsectional index and then the growth rate in each subsectional index is computed. Finally, the growth rates of each subsectional index are summed and weighted considering the subsectional asset sizes or trading volume.

Findings- The highest growth years in financial inclusion of banks; $15.26 \%$ in $2002,8.05 \%$ in 2009 , and $4.42 \%$ in 2014 . The lowest growth years in financial inclusion of banks; $-10.36 \%$ in 2001 and $-2.00 \%$ in 2008 . The average growth rate for banks for the 17 year period is $2.14 \%$. The highest growth years in financial inclusion of nonbanks; $24.47 \%$ in $2004,28.37 \%$ in $2006,26.34 \%$ in $2009,53.07 \%$ in 2010 , and $30.86 \%$ in 2014. The lowest growth years in financial inclusion of nonbanks; $-18.74 \%$ in $2001,-22.95 \%$ in 2011 and $-11.39 \%$ in 2016 . The average growth rate for nonbanks for the 17 year period is $6.19 \%$.

Conclusion- Financial inclusion simply means a larger size of financial institutions and a variety of financial products and services available for the use of adult individuals, businesses and governmental agencies. The existing literature advocate that the economic growth can be accelerated by an increase in financial inclusion. The empirical analysis for Turkey supports the literature where the growth in financial inclusion index enhances a higher growth in GDP and a much higher growth in GDP per capita. The project titled "Istanbul as an International Financial Center" may easily improve the level of financial inclusion in Turkey. For a sustainable economic growth and a fair income distribution in Turkey, the policy makers and administrators should set the rules and regulations to improve the financial inclusion.

Keywords: Financial inclusion, financial services, Turkish financial markets, financial indicators.

JEL Codes: G20, G21, G23

\section{REFERENCES}

Bozkurt, I., Karakuş, R., \& Yildiz, M. (2018). Spatial determinants of financial inclusion over time. Journal of International Development, 30(8), 1474-1504.

Chen, W., \& Yuan, X. (2021). Financial inclusion in China: an overview. Frontiers of Business Research in China, 15(1), 1-21. 
Correa, E., \& Girón, A. (2019). Financial inclusion and financialization: Latin American main trends after the great crisis. Journal of Economic Issues, 53(2), 496-501.

Dahiya, S., \& Kumar, M. (2020). Linkage between financial inclusion and economic growth: An empirical study of the emerging Indian economy. Vision, 24(2), 184-193.

Danisman, G. O., \& Tarazi, A. (2020). Financial inclusion and bank stability: Evidence from Europe. The European Journal of Finance, 26(18), 1842-1855.

Demirguc-Kunt, A., Klapper, L., Singer, D., \& Ansar, S. (2018). The Global Findex Database 2017: Measuring financial inclusion and the fintech revolution. World Bank Publications.

Demirgüç-Kunt, A., \& Singer, D. (2017). Financial inclusion and inclusive growth: A review of recent empirical evidence. World Bank Policy Research Working Paper, (8040).

Ezzahid, E., \& Elouaourti, Z. (2021). Financial Inclusion, Financial Frictions, and Economic Growth: Evidence from Africa. Journal of African Business, 1-26.

Ferrata, L. (2019). Digital financial inclusion-an engine for “leaving no one behind”. Public Sector Economics, 43(4), $445-458$.

Fouejieu, A., Sahay, R., Cihak, M., \& Chen, S. (2020). Financial inclusion and inequality: A cross-country analysis. The Journal of International Trade \& Economic Development, 29(8), 1018-1048.

Gopalan, S., \& Kikuchi, T. (2016). Financial inclusion in Asia. London: Palgrave Macmillan.

Gretta, S. A. A. B. (2017). Financial inclusion and growth. The Business \& Management Review, 8(4), 434-448.

Grohmann, A., Klühs, T., \& Menkhoff, L. (2018). Does financial literacy improve financial inclusion? Cross country evidence. World Development, 111, 84-96.

https://globalfindex.worldbank.org/\#GF-ReportChapters 